\title{
A new cryptic species of ground-dwelling Hemidactylus (Squamata: Gekkonidae) from southern India
}

\author{
Zeeshan A. Mirza \\ National Centre for Biological Sciences, Tata Institute of Fundamental Research, GKVK, Bellary Road, Bangalore 560065, \\ India. E-mail: snakeszeeshan@gmail.com.
}

\begin{abstract}
A new cryptic species of ground-dwelling Hemidactylus (Squamata: Gekkonidae) from southern India. Recently collected specimens of a gecko resembling Hemidactylus reticulatus from northern Karnataka State in southwestern India led me to investigate variation in the species with regards to its morphology and molecular divergence. Results based on existing museum material, combined with molecular data for the mitochondrial cytochrome $b$ gene support the presence of cryptic species within the broadly distributed $H$. reticulatus complex. Here, I describe a new species of Hemidactylus from northern Karnataka as the first contribution in resolving the species complex. The integration of molecular and morphological data supports the distinctness of the new species described herein.
\end{abstract}

Keywords: cytochrome $b$, phylogeny, species complex, taxonomy.

\begin{abstract}
Resumo
Uma nova espécie críptica de Hemidactylus (Squamata: Gekkonidae) terrestre do sul da Índia. Espécimes recentemente coletados de uma lagartixa semelhante a Hemidactylus reticulatus do norte do estado de Karnataka, no sudoeste da Índia, levou-me a investigar a variação na espécie relacionada à morfologia e divergência molecular. Os resultados baseados no material existente em museus, combinados com dados moleculares para o gene do citocromo $b$ mitocondrial suportam a presença de espécies crípticas dentro do complexo $H$. reticulatus, que possui distribuição ampla. Descrevo aqui uma nova espécie de Hemidactylus do norte de Karnataka como a primeira contribuição para a solução desse complexo de espécies. A integração de dados moleculares e morfológicos suporta o caráter distinto da nova espécie aqui descrita.
\end{abstract}

Palavras-chave: citocrome $b$, complexo de espécies, filogenia, taxonomia.

Received 16 August 2018

Accepted 02 October 2018

Distributed December 2018 


\section{Introduction}

The gekkonid lizard genus Hemidactylus Oken, 1817 is the second-most species-rich genus of geckos with at least 150 described species. It is most diverse is in the tropical regions of Asia and Africa. Although some species of Hemidactylus are commensal and widespread, there are several endemic lineages with restricted distributions (Carranza and Arnold 2005, Lajmi et al. 2016, 2018). India is home to at least 37 species 22 of which are endemic, and the number is steadily increasing as new habitats are explored and integrated taxonomic research that include molecular data are used to explore systematic relationships (Mirza et al. 2014, 2018, Mirza and Raju 2017, Chaitanya et al. 2018). Among Hemidactylus of the Indian subcontinent, Clade 7 (Lajmi et al. 2016) contains the following species: $H$. albofasciatus Grandison and Soman, 1963, $H$. sataraensis Giri and Bauer, 2008, H. gracilis Blanford, 1870, H. imbricatus (Bauer, Giri, Greenbaum, Jackman, Dharne and Shouche, 2008), and $H$. reticulatus Beddome, 1870 . These taxa are of interest because they are characterized by having poorly developed lamellae (unlike most members of the genus) and a short, robust habitus, and being strictly ground dwelling. These strictly nocturnal lizards inhibit open scrub areas, plateaus, and all except for $H$. albofasciatus and $H$. sataraensis occur in drier areas.

Hemidactylus reticulatus is a small, grounddwelling gecko widely distributed in the Indian states of Karnataka, Telangana, and Andhra Pradesh, as well as parts of Kerala and Tamil Nadu (Smith 1935, Murthy 1990, Tikader and Sharma 1992). Beddome (1870) described the species from Kollegal in south Karnataka and later, Smith (1935) mentioned its occurrence in Mysore and Polkonda Hills in Andhra Pradesh. Despite the wide range of the species, it is one of the most poorly known Indian gekkonid lizard and has had a stable systematic status since its description.
In the course of a biodiversity survey of Karnataka, I collected two specimens of a Hemidactylus from Bagalkot, northern Karnataka; superficially, these lizards resembled $H$. reticulatus based on the key presented by Smith (1935). However, when compared with types of $H$. reticulatus, these individuals are distinct and diagnosable. Based on my examination of additional specimens of $H$. reticulatus, I concluded that the specimens from Bagalkot represent a new species that is described here, along with notes on systematics of $H$. reticulatus.

\section{Materials and Methods}

Specimens were captured in the field by hand and euthanized following standard protocols (Leary et al. 2013); they were fixed in 6\% buffered formaldehyde before being washed and stored in $70 \%$ ethanol. The lizards are deposited in the collection of the National Centre for Biological Sciences, Bangalore.

\section{Morphological and Meristic Data}

The protocol for measurements is that of Mirza and Sanap (2014). Mitutoyo ${ }^{\mathrm{TM}}$ digital calipers (Mitutoyo Corporation, Kawasaki, Japan) were used to measure the following features to the nearest $0.1 \mathrm{~mm}$ : snout-vent length (SVL, tip of snout to vent); trunk length (TRL, posterior edge of forelimb insertion to anterior edge of hind-limb insertion; body width (BW, maximum width of body); crus length (CL, base of heel to knee); tail length (TL, vent to tip of tail); tail width (TW, widest part of tail); head length (HL, retroarticular process of jaw to tip of snout); head width (HW, maximum width); head height $(\mathrm{HH}$, maximum height, from occiput to underside of jaws); forearm length (FL, base of palm to elbow); ear length (EL, longest dimension of ear); orbital diameter (OD, greatest diameter of orbit); nares-eye distance (NE, anterior margin of eye to nostril); snout-eye distance (SE, anterior margin of eye to tip of snout); eye-ear distance (EE, anterior edge of 
ear opening to posterior corner of eye); internarial distance (IN, naris to naris); and interorbital distance (IO, shortest distance between left and right supraciliary scale rows) (Table 1). A Leica $^{\mathrm{TM}}$ S8APO (Leica Camera, Wetzlar, Germany) dissecting microscope was used to obtain meristic counts and examine external morphology. Images of the specimens were obtained with a Canon ${ }^{\mathrm{TM}}$ 70D mounted with a Canon $^{\mathrm{TM}} 100 \mathrm{~mm}$ macro illuminated with two external Canon ${ }^{\mathrm{TM}}$ 430EX-II flashes (Canon Inc., Tokyo, Japan). Institutional codes are as follow: NHM, Natural History Museum London; NCBS, collection facility of National Centre for Biological Sciences, Bangalore; and CES, Centre for Ecological Sciences, Bangalore.

\section{Molecular Analysis}

DNA was extracted from tail tissue of the female paratype with a HiMedia ${ }^{\mathrm{TM}}$ mammalian genomic DNA extraction kit and following protocol directed by the manufacturers. A partial segment of mitochondrial cytochrome $b$ gene, which has been shown to have phylogenetic signal in Hemidactylus was amplified. Primer pairs reported and used by previous researchers were used: Cytbl (5'-CCATCCAACATCTCAG CATGATGAAA-3') and Cytb2 (5'-ACTGTAG CCCCTCAGAATGATATTTGTCCTCA-3') (Kocher et al. 1989). A 2- $\mu \mathrm{L}$ reaction was set containing $12.5 \mu \mathrm{L}$ of $\mathrm{HiMedia}^{\mathrm{TM}}$ Taq PCR Master Mix, $12.5 \mu \mathrm{L}$ of water, $0.5 \mu \mathrm{L}$ of each primer, and a $1-\mu \mathrm{L}$ template DNA was carried out with an Eppendorf Mastercycler Nexus GSX1. The thermo-cycle profile used for amplification of $C y t b$ is that of Mirza et al. (2017), as follows: $94^{\circ} \mathrm{C}$ for $5 \mathrm{~min}$ (denaturation temperature $94^{\circ} \mathrm{C}$ for $30 \mathrm{~s}$, annealing temperature $59.1^{\circ} \mathrm{C}$ for $50 \mathrm{~s}$, elongation temperature $72^{\circ} \mathrm{C}$ for $2 \mathrm{~min}) \times 35$ cycles; $72^{\circ} \mathrm{C}$ for $15 \mathrm{~min}$; and hold at $4^{\circ} \mathrm{C}$. PCR product was cleaned with a HiMedia ${ }^{\mathrm{TM}}$ PCR Purification Kit and sequenced with a 3730 DNA Analyzer. Sequences for Cytb gene of selected Hemidactylus spp. of the "brookii group" of Bauer et al. (2010) were obtained
Table 1. Morphological and meristic data for two specimens of Hemidactylus vijayraghavani sp. nov. Abbreviations: SVL, snout-vent length; $\mathrm{TRL}$, trunk length; BW, body width; $\mathrm{CL}$, crus length; TL, tail length; TW, tail width; HL, head length; HW, head width; $\mathrm{HH}$, head height; FL, forearm length; EL, ear length; OD, orbital diameter; $\mathrm{NE}$, nares-eye distance; $\mathrm{SE}$, snout-eye distance; EE, eye-ear distance; IN, internarial distance; $\mathrm{IO}$, interorbital distance. An * indicates broken or regenerated tail.

\begin{tabular}{|c|c|c|}
\hline & NCBS BH643 & NCBS BH644 \\
\hline & Holotype & Paratype \\
\hline Sex & $0^{x}$ & $0^{x}$ \\
\hline SVL & 36.6 & 38.5 \\
\hline $\mathrm{TRL}$ & 17.7 & 16.3 \\
\hline BW & 7.8 & 8.6 \\
\hline $\mathrm{CL}$ & 5.1 & 6.4 \\
\hline $\mathrm{TL}$ & 37.9 & $6.5^{*}$ \\
\hline TW & 3.8 & 4.2 \\
\hline $\mathrm{HL}$ & 8 & 9 \\
\hline $\mathrm{HW}$ & 7.9 & 7.9 \\
\hline $\mathrm{HH}$ & 4.2 & 4.5 \\
\hline $\mathrm{FL}$ & 4.9 & 4.7 \\
\hline OD & 2.3 & 2.5 \\
\hline $\mathrm{NE}$ & 2.9 & 3.1 \\
\hline SE & 3.8 & 4.2 \\
\hline $\mathrm{EE}$ & 3.2 & 3.4 \\
\hline EL & 0.5 & 0.5 \\
\hline IN & 1.3 & 1.4 \\
\hline $\mathrm{IO}$ & 3.4 & 2.9 \\
\hline Pores & 8 & - \\
\hline \multicolumn{3}{|l|}{ Lamellae } \\
\hline Left manus & $6-7-7-7-6$ & $6-8-8-8-8$ \\
\hline Right manus & $6-7-7-7-7$ & $6-8-8-8-8$ \\
\hline Left pes & $6-7-8-8-8$ & $7-8-9-9-8$ \\
\hline Right pes & $6-7-8-8-8$ & $7-8-9-9-8$ \\
\hline Supralabials L/R & $9 / 9$ & $8 / 9$ \\
\hline Infralabials L/R & $7 / 7$ & $7 / 7$ \\
\hline Scales across belloy & 42 & 40 \\
\hline
\end{tabular}


from GenBank; all members of the grounddwelling clade, including $H$. scabriceps (Annandale, 1906), were included. Downloaded sequences were aligned in MEGA6 (Kumar et al. 2016) with ClustalW (Thompson and Gibson 2002) at default settings. To obtain the optimal partitioning strategy, aligned data were analyzed with PartitionFinder v.1.1.1 (Lanfear et al. 2012) and evolutionary substitution models were selected based on Akaike information criterion (AIC) values individually for Maximum Likelihood and Bayesian Inference. Phylogenetic relationships under Maximum Likelihood were assessed using RAxML (Silvestro and Michalak 2012). Data were partitioned into three codons and GTR + G was used as the sequence substitution model, based on the optimal partitioning scheme suggested by PartitionFinder. One thousand non-parametric bootstrap replicates were run using the rapid ML search option to assess topological support. Bayesian Inference was implemented in MyBayes 3.2.2. (Ronquist and Huelsenbeck 2003) and was run for 10 million generations and terminated after the analysis reached a standard split frequency of 0.05 . Twenty-five percent of trees generated were discarded as burnin. Sequence divergences, as uncorrected p-distances, were calculated in Mega6. GenBank accession number for the sequence generated for the paratype female is MH494347.

\section{Results}

\section{Hemidactylus vijayraghavani sp. nov.} (Figures 1-3, Table 1)

Holotype.-NCBS-BH643, an adult male from Bagalkot, Karnataka, India $\left(16.139744^{\circ} \mathrm{N}\right.$, $75.672671^{\circ} \mathrm{E}, 590 \mathrm{~m}$ a.s.1.) collected by Arya Murthy, Mayuresh Ambekar, and Zeeshan Mirza on 14 April 2018.

Paratype.-NCBS-BH644, an adult female with same data as holotype.
Defininition.-A small, fairly stout gecko, ranging in SVL from 36-38.5 mm. Dorsum light brown with reticulate pattern. Dorsal scalation on trunk granular, homogenous, with irregular row of 8-10 smooth, rounded tubercles. Tubercles subequal to adjacent dorsal granular scales. An angular series of 8 precloacal pores in males.

Species comparisons.-Hemidactylus vijayraghavani sp. nov. differs from most Indian congeners in having the following combination of characters: (1) SVL 36-38.5 mm (vs. > 60 mm in H. maculatus Duméril and Bibron, 1836; H. graniticolus Agarwal, Giri, and Bauer, 2011; H. giganteus Stoliczka, 1871; H. gujaratensis Giri, Bauer, Vyas, and Patil, 2009; H. prashadi Smith, 1935; H. acanthopholis Mirza and Sanap, 2014; H. paaragowli Srikanthan, Swamy, Mohan, and Pal, 2018; H. kangerensis Mirza, Bhosale, and Patil, 2017; H. sushilduttai Giri, Bauer, Mohapatra, Srinvasulu, and Agarwal, 2017; H. siva Srinivasulu, Srinivasulu, and Kumar, 2018; H. aaronbaueri Giri, 2008; $H$. yajurvedi Murthy, Bauer, Lajmi, Agarwal, and Giri, 2015). (2) Tubercles on dorsum not keeled arranged in longitudinal rows (vs. tubercles absent or few or irregularly arranged in $H$. aquilonius $\mathrm{Zug}$ and Mcmahan, 2007; $H$. flaviviridis Rüppell, 1835; H. frenatus Duméril and Bibron, 1836; H. garnotii Duméril and Bibron, 1836; H. leschenaultii Duméril and Bibron, 1836; H. hemchandrai Dandge and Tiple, 2015). (3) Tubercle rows 8-10 (vs. > 15 in H. gleadowi Murray, 1884; H. kushmorensis Murray, 1884; H. parvimaculatus Deraniyagala, 1953; H. chipkali Mirza and Raju, 2017; $H$. malcolmsmithi Constable, 1949; H. persicus Anderson, 1872; H. robustus Heyden, 1827; $H$. turcicus Linnaeus, 1758). (4) Dorsal tubercles smooth and rounded [vs. tubercles trihedral in $H$. triedrus (Daudin, 1802); H. sahgali Mirza, Gowande, Patil, Ambekar, and Patel, 2018; and sub-trihedral in $H$. whitakeri Mirza, Gowande, Patil, Ambekar, and Patel, 2018]. (5) Webbing absent on hind feet and a fringe of skin on lateral 

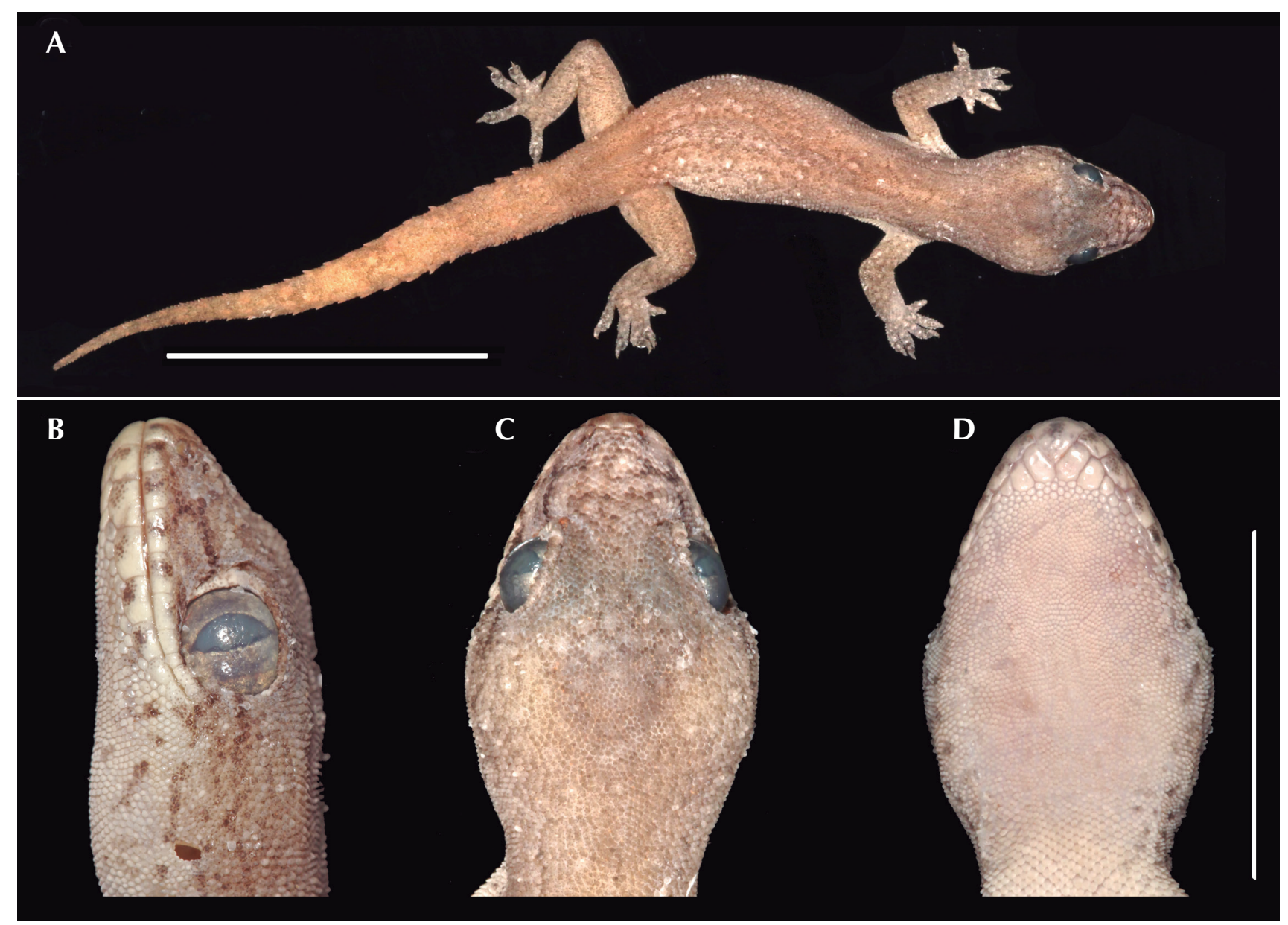

Figure 1. Male holotype of Hemidactylus vijayraghavani sp. nov., NCBS-BH643. (A) Dorsal aspect, scale $=20 \mathrm{~mm}$. (B-D) View of lateral, dorsal, and ventral head, respectively; scale $=10 \mathrm{~mm}$.

aspect of tail [vs. present in $H$. platyurus (Schneider, 1797)]. (6) Digital lamellae divided [vs. undivided in $H$. anamallensis (Günther, 1875)].

The new species belongs to the grounddwelling clade of Hemidactylus and is compared below with all known members of the clade. The dorsum has reticulate dark markings with white spots in their interspaces, whereas in $H$. sataraensis, there are four stripes with transversely arranged spots. Hemidactylus gracilis has two stripes with a gray spotted dorsum. The dorsum and tail $H$. albofasciatus has light streaks. The scales on dorsal aspect of trunk are juxtaposed in the new species, whereas they are imbricate in $H$. scabriceps.
In general appearance and genetic data, the new species is most similar to $H$. reticulatus from which it differs in having homogenous granular scales on dorsal aspect of trunk (vs. scales heterogeneous in $H$. reticulatus). The tubercles in the new species are smaller than the adjacent granular scales (vs. tubercles twice the size of the adjacent granular scales in $H$. reticulatus). The new species bears $8-10$ rows of tubercles on its dorsum (vs. 13-14 in $H$. reticulatus).

Description of holotype.-Well preserved adult male $36.6 \mathrm{~mm}$ SVL, lacking any incisions or cuts. A small gecko with a fairly large head (HL/ SVL ratio 0.22 ) nearly as long as wide (HW/HL 


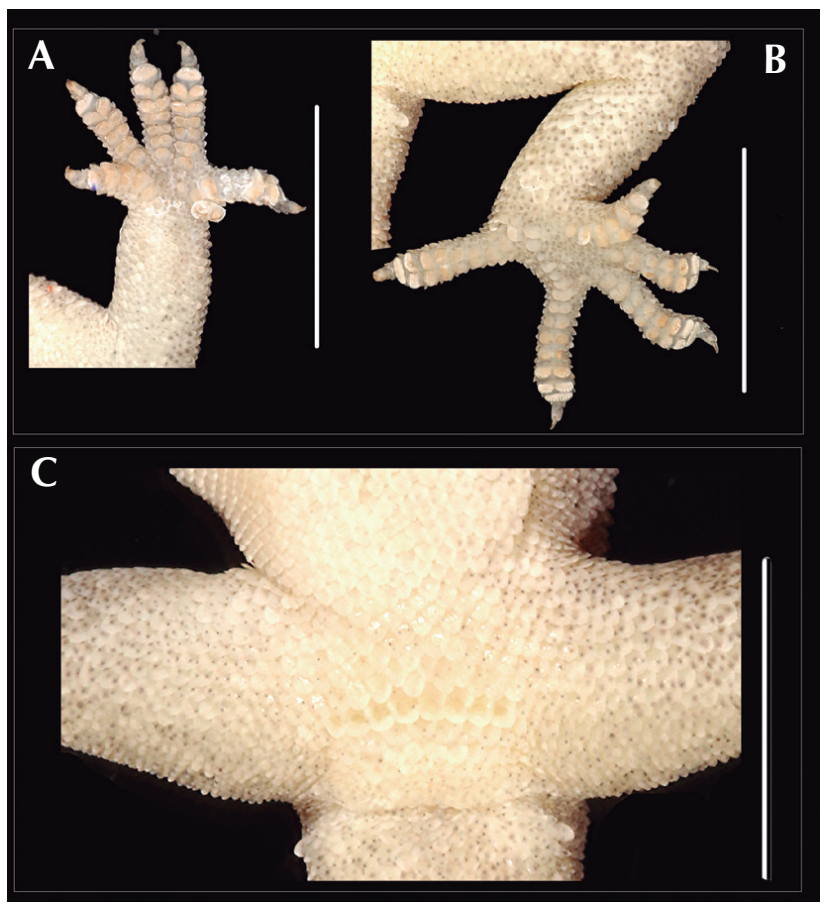

Figure 2. Male holotype of Hemidactylus vijayraghavani sp. nov., NCBS-BH643. (A) Left manus. (B) Left pes. (C) Venter showing precloacal pores. Scale $=5 \mathrm{~mm}$.

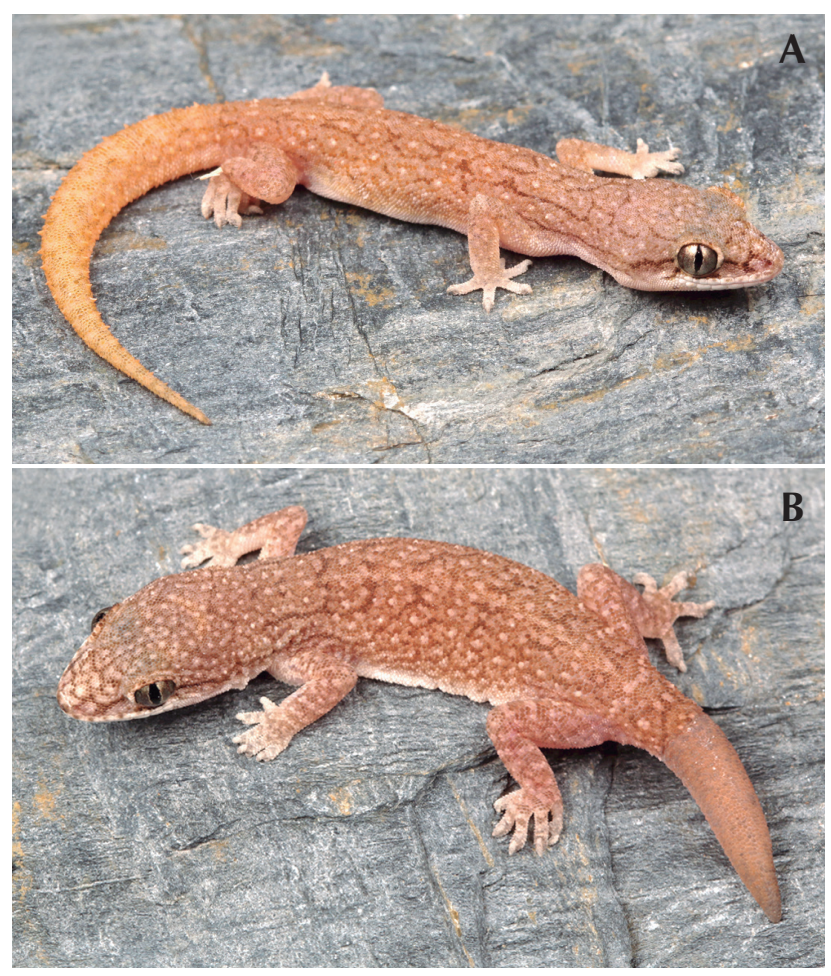

Figure 3. Hemidactylus vijayraghavani sp. nov. in life. (A) Male holotype, NCBS-BH643. (B) Female paratype, NCBS-BH644. ratio 0.98); head depressed (HH/HL ratio 0.52), distinct from neck (Figure 1A). Canthus rostralis slightly inflated; snout short (SE/HW ratio 0.48), obtusely pointed in dorsal aspect and acute in lateral aspect (Figure 1B), longer than eye diameter (OD/SE ratio 0.6). Scales on snout subequal, convex; those anterior to the eye and on canthus rostralis larger than surrounding scales. Eyes large (OD/HL ratio 0.29), pupil vertical with crenulated edges. Supraciliaries larger on anterior edge of orbit, gradually decreasing in size posteriorly. Ear opening large, suboval, obliquely oriented, length less than half orbital diameter (EL/OD ratio 0.21); lobules absent; eye-ear distance greater than diameter of eye (EE/OD ratio 1.39). Rostral quadrangular, much wider than deep, with median suture for its entire length; rostral in contact with nasal, first supralabial, and internasals; two large and a slightly smaller internasal between nasals; mental triangular, slightly wider (1.48) than long (1.2); two pairs of postmentals; anterior postmental longer (1.08) than wide (0.885); posterior pair of postmentals smaller than anterior pair, longer (0.94) than wide (0.59); anterior postmental in contact with mental, infralabial one and two, and posterior pair of postmentals; posterior postmentals slightly smaller than anterior ones; anterior postmental narrower than first infralabial; posterior postmental half as wide as second infralabials; posterior postmental in contact with anterior postmental, first and second infralabials; posterior borders of postmentals not in alignment; three rows of large scales bordering the infralabial scales with postmentals separating these from much smaller throat scales (Figure 1D); scales on throat circular, smaller than scales on ventral aspect of trunk; supralabials (to midorbital position) seven on left and right sides; supralabials (to angle of jaw) 9/9; infralabials (to angle of jaw) $7 / 7$.

Body elongate (TRL/SVL ratio 0.48 ) and dorsoventrally flattened, lacking distinct ventrolateral furrow; dorsal scalation on trunk granular intermixed with smooth, rounded 
tubercles lacking keels; 8-10 longitudinal, slightly depressed tubercle rows; ventral scales on trunk smooth, flat, larger than dorsal scales; midbody scales across belly 42,8 precloacal pores at mid-pelvic region (Figure 2C).

Limbs moderately long, stout; digits dilated, bearing horizontally oriented lamellae on ventral surface; lamellae on basal half of Digit I of manus and pes undivided, other lamellae (excluding terminal lamellae) divided; clawed, claw slightly smaller than length of lamellar region. Forelimbs short (FL/SVL ratio 0.13), slightly shorter than hind limbs (CL/SVL ratio 0.14). Terminal phalanx of each digit curved, oriented at an angle from distal portion of expanded lamellar pad; free portion of phalanx of each digit half to more than half long as dilated portion. Lamellae beneath the digits: 6-77-7-6 (Figure 2A) on left, 6-7-7-7-7 on right manus; 6-7-8-8-8 on left and right pes (Figure 2B). Lamellae not reaching the base of Digit IV of pes, covering $80 \%$ of digit. Relative lengths of digits: III $>$ IV $>$ I $>$ V $>$ I (left manus), IV $>$ III $>$ V $>$ II $>$ I (left pes).

Tail moderately depressed, oval in cross section, nearly as long as snout-vent length (TL/ SVL ratio 1.03). Caudal segments distinct, pholidosis of original tail dorsum with small, juxtaposed scales intermixed with large keeled trihedral tubercles. First tail segment with a whorl of 8 large, conical, keeled tubercles; second and posterior segments each with 6 tubercles. Venter with large, imbricate scales. One subconical postcloacal spur.

Coloration in life (Figure 3A, B).--Ground color of head, trunk, and tail light brown; a tinge of pink on limbs; brown reticulate pattern on ground color. Spaces enclosed by reticulate pattern usually with whitish or cream-colored spot. Tail with a yellowish orange tinge. Venter white; black markings absent on chin and labial shields. Labials with diffused black patches. Color in preservative faded relative to color in life. White spots more prominent in the preserved specimen.
Natural history.-The species inhabits dry, open scrub and rock terrain in northern Karnataka. The type locality is a barren hillock adjacent to a seasonal river. The locality is heavily disturbed from activities relating to stone quarrying. Two individuals were found in $2 \mathrm{hr}$. The geckos actively forage between 1900-1945 hr. Other sympatric reptiles include Eutropis cf. carinata, Hemidactylus parvimaculatus, and Sitana sp. The new species currently known only from the type locality.

Etymology.-The specific epithet is a patronym honoring Prof. K. VijayRaghavan of the National Centre for Biological Sciences, Bangalore for his efforts to enhance science research and education in India. Prof. K. VijayRaghavan is a Fellow of the Royal Society (London) and Principal Scientific Advisor to the Government of India.

\section{Discussion}

Phylogenetic relationships of the major species groups of Indian Hemidactylus are well resolved (Bauer et al. 2008, 2010, Bansal and Karanth 2010, Lajmi et al. 2016). These studies present data documenting the high genetic divergence in currently recognized species, and thus, suggest that distinct and cryptic species may be present (Mirza et al. 2017, 2018). Hemidactylus vijayraghavani sp. nov. is just one species, among many others, that had been included in a prior phylogenetic analysis under voucher number CES11016 (Lajmi et al. 2016, 2018) and was considered to be conspecific with $H$. reticulatus. Hemidactylus vijayraghavani sp. nov. is embedded within the ground-dwelling clade (Figure 4) that includes $H$. gracilis, $H$. imbricatus, $H$. sataraensis, and $H$. reticulatus. This new species is well supported $(\mathrm{ML}=87+$ $\mathrm{BI}=1)$ as the sister taxon of the clade $[H$. cf. reticulatus $+H$. reticulatus], which in turn, is the sister lineage of $H$. sataraensis. Hemidactylus vijayraghavani $\mathrm{sp}$. nov. has an uncorrected p-distance of $9-11 \%$ from other members of the H. reticulatus Complex (Table 2, Appendix I). 


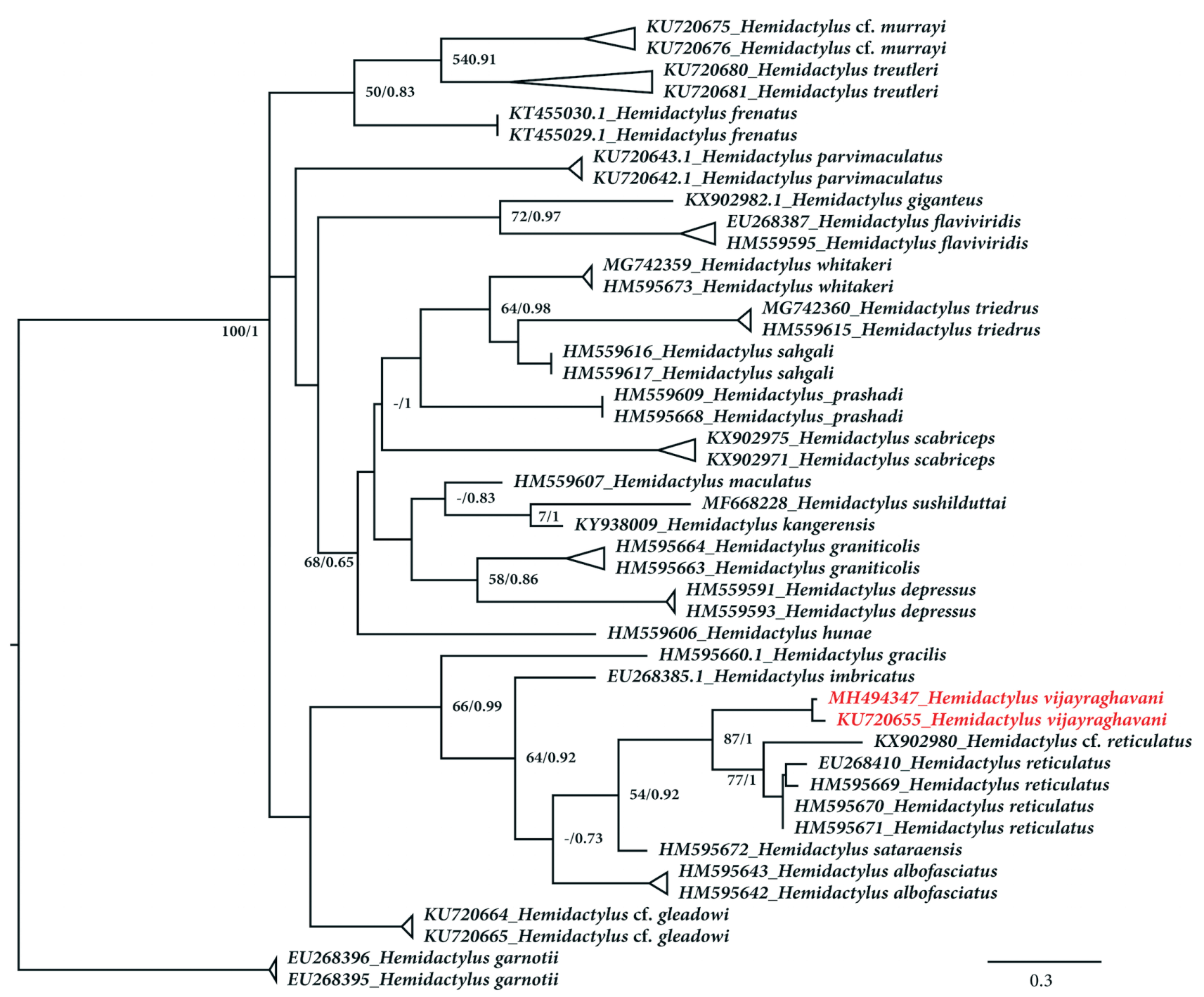

Figure 4. Maximum likelihood phylogeny of selected members of the genus Hemidactylus based on cyt $b$ gene. Numbers at nodes represent ML bootstrap and BI posterior probability support. Only ML support > 50 are shown. The new species is shown in red text.

Morphologically, the new species differs from members of the $H$. reticulatus Complex in having homogeneous granular scales on the trunk rather than heterogeneous scales (Figure $5)$.

Hemidactylus reticulatus is widely distributed across drier areas of southern Indian Peninsula (Figure 6); the range of the species spans several biogeographic zones interrupted by rivers, ranges of hills, and varying altitudes. These geographical features may affect gene flow. The Bangalore-
Mysore Plateau is a major topographical feature in the range of $H$. reticulatus. The area harbors distinct lineages of gekkonid lizards, such as $H$. whitakeri (Mirza et al. 2018) and Cyrtodactylus srilekhae Agarwal, 2016 (Agarwal 2016). Hemidactylus vijayraghavani seems to be isolated from members of the $H$. reticulatus Complex by two major rivers-viz., the Krishna and Tungabhadra rivers. A similar situation seems to prevail in the sympatric agamid genus Sitana (Mirza pers. obs., under review) for which the rivers seem to pose biogeographic barriers 

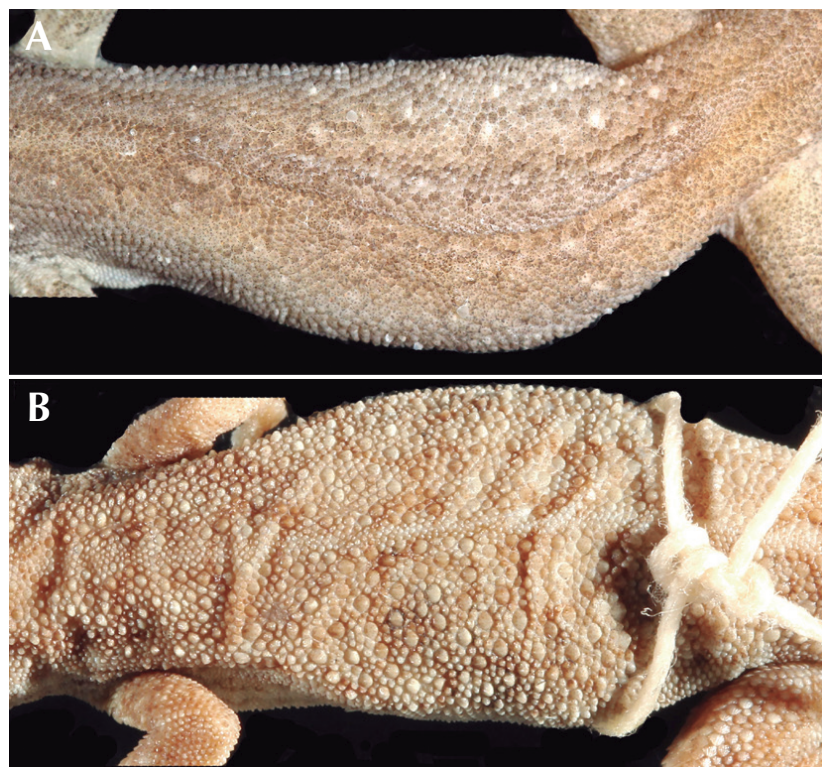

Figure 5. Dorsal scalation on trunk. (A) Male holotype of Hemidactylus vijayraghavani sp. nov., NCBS-BH64. (B) Male syntype of $H$. reticulatus, NHM 1874.4.29.410.

for these terrestrial lizards (Deepak et al. 2016, Deepak and Karanth 2017). Confirmation of this speculation, however, will require more sampling across major rivers flowing though the range of the H. reticulatus Complex (Figure 7).

The ground-dwelling clade is composed of Hemidactylus vijayraghavani, H. albofasciatus, $H$. sataraensis, H. gracilis, H. imbricatus, and $H$. reticulatus; this clade is distributed in the

Table 2. Un-corrected p-distance for ground dwelling members of the Hemidactylus brookii clade for Cytb gene.

\begin{tabular}{lc}
\hline Species & H. vijayraghavani sp. nov. \\
\hline H. cf. reticulatus & 9.8 \\
H. reticulatus $(N=4)$ & $10.3-11.2$ \\
H. gracilis & 19.2 \\
H. albofasciatus $(N=2)$ & $14.5-15.9$ \\
H. imbricatus & 12 \\
H. sataraensis & 10.2 \\
\hline
\end{tabular}

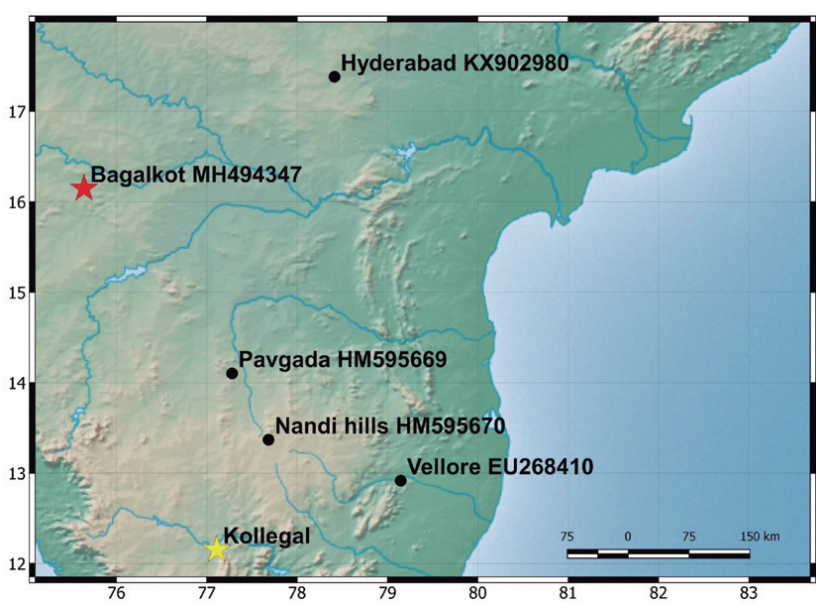

Figure 6. Distribution of Hemidactylus vijayraghavani sp. nov. and members of the $H$. reticulatus Complex. Stars indicate type localities. Red: Hemidactylus vijayraghavani sp. nov. Yellow: $H$. reticulatus. Numbers with localities are GenBank accession numbers.

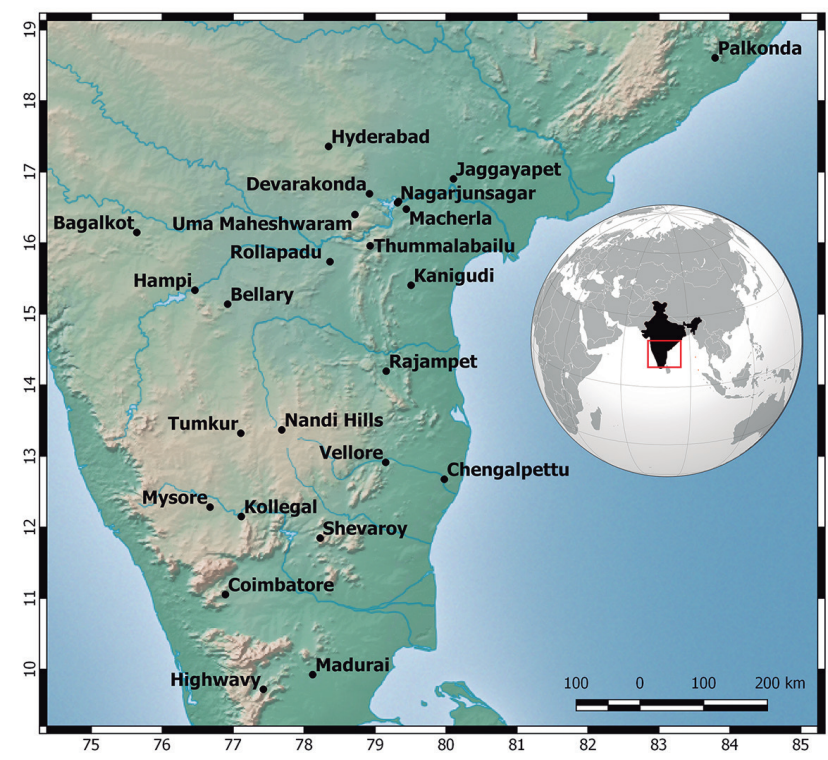

Figure 7. Known localities for members of the Hemidactylus reticulatus Complex.

Indian Peninsula south of the Narmada Valley, with a single species occurring in district of Sindh in Pakistan. The Narmada Valley likely is a biogeographic barrier for the ground-dwelling clade, as well as large bodied, tuberculate Hemidactylus. The ground-dwelling clade diverged 
from $H$. cf. gleadowi about 22 MYA and within clade diversification dates between 8 and 15 MYA (Lajmi et al. 2018). This diversification is coincident with mid-Miocene aridification and the onset of Indian monsoons, and resembles that of the genus Sitana, which occupies the southern Indiana Peninsula (Deepak and Karanth 2017).

The biodiversity of arid regions of India has largely been ignored because such areas usually are considered to be homogenous. However, molecular data generated for lizards inhibiting arid regions reveal previously overlooked diversity (Agarwal and Ramakrishnan 2017, Deepak and Karanth 2017). The results presented here contribute to our understanding of species diversity across these arid regions, and suggest that a systematic study of $H$. reticulatus based on new material collected from its entire range is likely to result in discovery of several additional undescribed lineages.

\section{Acknowledgments}

I wish to acknowledge K. VijayRaghavan for hosting me and supporting my work at the National Centre for Biological Sciences. Part of the study was supported by the Singinawa Conservation Foundation through Tulika Kedia. I am indebted to the NCBS Sanger Sequencing Facility for help with sequencing, to Krushnamegh Kunte (NCBS), who helped with registration of the types, and Gaurang Gowande, who provided valuable comments on the final draft of the manuscript. Fieldwork would not have been possible without the help of Arya Murthy and Mayuresh Ambekar. I thank David Gower and Patrick Campbell (Natural History Museum, London) for hosting me and granting access to specimens in their collection. ZM was able to visit the Natural History Museum, London through a travel grant from the Newby Trust Limited. Special thanks to Aaron Bauer and an anonymous reviewer for their lucid comments from which the manuscript greatly benefited.

\section{References}

Agarwal, I. 2016. Two new species of ground-dwelling Cyrtodactylus (Geckoella) from the Mysore Plateau, south India. Zootaxa 4193: 228-244.

Agarwal, I. and U. Ramakrishnan. 2017. A phylogeny of open-habitat lizards (Squamata: Lacertidae: Ophisops) supports the antiquity of Indian grassy biomes. Journal of Biogeography 44: 2021-2032.

Bansal, R. and K. P. Karanth. 2010. Molecular phylogenetics and evolution molecular phylogeny of Hemidactylus geckos (Squamata: Gekkonidae) of the Indian subcontinent reveals a unique Indian radiation and an Indian origin of Asian house geckos. Molecular Phylogenetics and Evolution 57: 459-465.

Bauer, A. M., T. R. Jackman, E. Greenbaum, V. B. Giri, and A. De Silva. 2010. South Asia supports a major endemic radiation of Hemidactylus geckos. Molecular Phylogenetics and Evolution 57: 343-352.

Bauer, A. M., V. B. Giri, E. Greenbaum, T. R. Jackman, M. S. Dharne, and Y. S. Shouche. 2008. On the systematics of the gekkonid genus Teratolepis Günther , 1869 : another one bites the dust. Hamadryad 32: 90104.

Beddome, H. 1870. Descriptions of some new lizards from the Madras Presidency. Madras Monthly Journal of Medicinal Scienceq 1: 30-35.

Carranza, S. and E. N. Arnold. 2005. Systematics, biogeography, and evolution of Hemidactylus geckos (Reptilia: Gekkonidae) elucidated using mitochondrial DNA sequences. Molecular Phylogenetics and Evolution 28: $531-545$.

Chaitanya, R., A. Lajmi, and V. B. Giri. 2018. A new cryptic, rupicolous species of Hemidactylus Oken, 1817 (Squamata: Gekkonidae) from Meghamalai, Tamil Nadu, India. Zootaxa 4374: 49-70.

Deepak, V. and P. Karanth. 2017. Aridification driven diversification of fan-throated lizards from the Indian subcontinent. Molecular Phylogenetics and Evolution 120: 53-62.

Deepak, V., V. B. Giri, M. Asif, S. K. Dutta, R. Vyas, A. M. Zambre, H. Bhosale, and K. P. Karanth. 2016. Systematics and phylogeny of Sitana (Reptilia: Agamidae) of Peninsular India , with the description of one new genus and five new species. Contributions to Zoology 85: 67-111.

Kocher, T., W. Thomas, and A. Meyer. 1989. Dynamics of mitochondrial DNA evolution in animals: amplification and sequencing with conserved primers. Proceedings of 
the National Academy of Sciences of United States 86: 6196-6200.

Kumar, S., G. Stecher, and K. Tamura. 2016. MEGA7: Molecular Evolutionary Genetics Analysis version 7.0 for bigger datasets. Molecular Biology and Evolution 33: 1870-1874.

Lajmi, A., R. Bansal, V. Giri, and P. Karanth. 2018. Phylogeny and biogeography of the endemic Hemidactylus geckos of the Indian subregion suggest multiple dispersals from Peninsular India to Sri Lanka. Zoological Journal of the Linnean Society 47: 1-16.

Lajmi, A., V. B. Giri, and P. K. Karanth. 2016. Molecular data in conjunction with morphology help resolve the Hemidactylus brookii complex (Squamata : Gekkonidae). Organisms Diversity and Evolution 16: 659-677.

Lanfear, R., B. Calcott, S. Ho, and S. Guindon. 2012. PartitionFinder: combined selection of partitioning schemes and substitution models for phylogenetic analyses. Molecular Biology and Evolution 29: 16951701 .

Leary, S., W. Underwood, R. Anthony, and S. Cartner. 2013. AVMA Guidelines for the Euthanasia of Animals: 2013 Edition. Schaumburg. American Veterinary Medical Association. 102 pp.

Mirza, Z. and R. Sanap. 2014. A new cryptic species of gecko of the genus Hemidactylus Oken, 1817 (Reptilia: Gekkonidae) from Southern India. Taprobanica 6: 12-20.

Mirza, Z. A. and D. Raju. 2017. A new rupicolous species of gecko of the genus Hemidactylus Oken, 1817 from the Satpura Hills, Central India. Amphibian and Reptile Conservation 11: 51-71.
Mirza, Z. A., H. Bhosale, and R. Patil. 2017. A new large species of gecko of the genus Hemidactylus Oken, 1817 (Reptilia: Sauria: Gekkonidae) from the Eastern Ghats, India. Comptes Rendus Biologies 340: 531-540.

Mirza, Z. A., S. Pal, H. Bhosale, and R. Sanap. 2014. A new species of gecko of the genus Cnemaspis Strauch, 1887 from the Western Ghats, India. Zootaxa 3815: 494-506.

Mirza, Z. A., G. G. Gowande, R. Patil, M. Ambekar, and H. Patel. 2018. First appearance deceives many: disentangling the Hemidactylus triedrus species complex using an integrated approach. PeerJ 6: e5341.

Murthy, T. 1990. A field book of the lizards of India. Records of Zoological Survey of India. Occasional Papaer 115: 1-122.

Ronquist, F. and J. Huelsenbeck. 2003. MrBayes 3: Bayesian phylogenetic inference under mixed models. Bioinformatics 19: 1572-1574.

Silvestro, D. and I. Michalak. 2012. RaxmlGUI: a graphical front-end for RAxML. Organisms Diversity and Evolution 12: 335-337.

Smith, M. A. 1935. The Fauna of British India, Including Ceylon and Burma. Reptilia and Amphibia. Volume II. Sauria. London. Taylor and Francis. 440 pp.

Thompson, J. and T. Gibson. 2002. Multiple sequence alignment using ClustalW and ClustalX. Current Protocols in Bioinformatics, Chapter 2: Unit 2.3.

Tikader, B. K. and R. C. Sharma. 1992. Handbook of Indian Lizards. Calcutta. Zoological Survey of India. 250 pp.

Editor: Jaime Bertoluci 


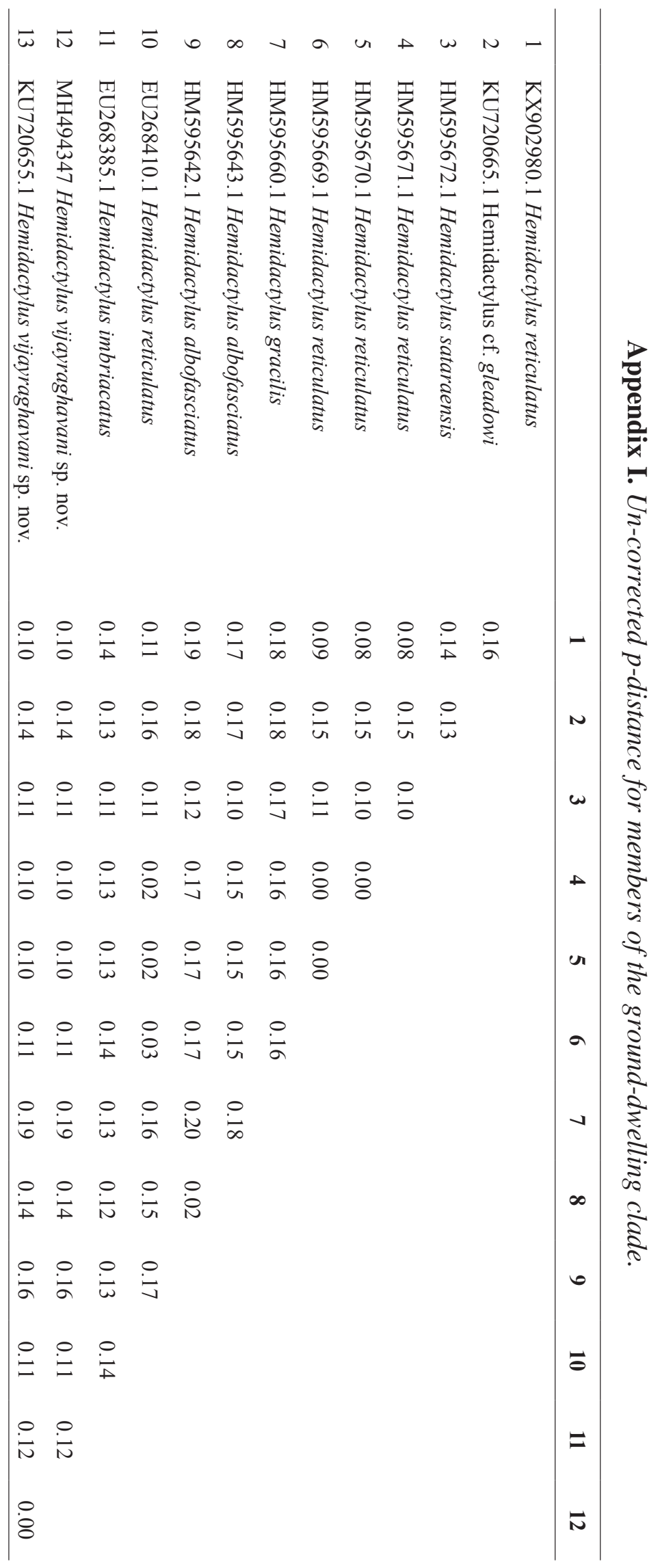

